\title{
Selection response for milk production in conventional production systems in Mexico, using genetic evaluations of Holstein sires from Canada and the United States
}

\author{
H. H. Montaldo, ${ }^{\star 1}$ S. G. Núñez-Soto,† F. J. Ruiz-López,ł and H. Castillo-Juárez§ \\ *Departamento de Genética y Bioestadística, Facultad de Medicina Veterinaria y Zootecnia, Universidad Nacional Autónoma de México, Ciudad \\ Universitaria, 04510, Distrito Federal, México \\ †Comité Estatal de Fomento y Protección Pecuaria de Guerrero, Servicio Nacional de Sanidad, Inocuidad y Calidad Agroalimentaria, Secretaria \\ de Agricultura, Ganadería, Desarrollo Rural, Pesca y Alimentación, 39095, Guerrero, México \\ $\ddagger$ Centro Nacional de Investigación en Fisiología y Mejoramiento Animal, Instituto Nacional de Investigaciones Forestales, Agrícolas y Pecuarias; \\ Secretaria de Agricultura, Ganadería, Desarrollo Rural, Pesca y Alimentación, 76280, Querétaro, México \\ $\S$ Departamento de Producción Agrícola y Animal, Universidad Autónoma Metropolitana-Xochimilco Calzada del Hueso 1100, 04960, Distrito \\ Federal, México
}

\section{ABSTRACT}

Polynomial regression models of the first, second, and third order were used to fit milk production deviations of daughters in Mexico on Canadian and US predicted transmitting ability values for 305 -d mature-equivalent milk production $(\mathrm{kg})$. For the pairs Canada-Mexico and Mexico-United States, 40 and 73 bulls with a minimum reliability of 0.75 were analyzed, respectively. Genetic correlations between pairs of countries were also estimated. The parameters were evaluated for all data, and for sires grouped according to the mean of the average phenotypic milk production (high and low) of their daughters' herd mates. Quadratic and cubic effects were not significant in any analysis. From linear regression models, slopes of Mexican daughter deviations on US and Canadian predicted transmitting abilities were 1.01 and 0.93 , respectively. Slopes were greater but intercepts were smaller for the high versus low level of production of the sires' herd mates in Mexico. A greater difference between the genetic correlations was found for the high versus low environmental level than for the low level (0.79 vs. 0.70) for Mexico-US data compared with Canada-Mexico data (0.81 vs. 0.78). Genetic correlations between Mexico and the United States (0.74), and between Mexico and Canada (0.77), were smaller than the genetic correlation between the same Canadian and US sires (0.92), suggesting the presence of a moderate degree of genotype-environment interaction for milk production between Canada and the United States, and Mexico.

Key words: selection response, milk production, sire evaluation, Mexico

Received February 19, 2009.

Accepted July 1, 2009.

${ }^{1}$ Corresponding author: montaldo@servidor.unam.mx

\section{INTRODUCTION}

In 2005, the dairy cow population in Mexico consisted of approximately 2.2 million animals (Servicio de Información Agroalimentaria y Pesquera, Secretaría de Agricultura, Ganadería, Desarrollo Rural, Pesca y Alimentación, 2009). In 2007, the specialized dairy population consisted of approximately 0.85 million cows, and animals were raised mainly in temperate areas in the high plateaus of central Mexico and in the arid areas of northern Mexico under intensive and semiintensive systems. This specialized dairy population, mostly Holstein, in 2007 accounted for approximately $50 \%$ of the total milk production of 10.3 million tons in the country, and that proportion is increasing (Servicio de Información Agroalimentaria y Pesquera, Secretaría de Agricultura, Ganadería, Desarrollo Rural, Pesca y Alimentación, 2009).

The number of cows in official milk recording by the Holstein Association for genetic evaluation purposes was approximately 42,000 in 2008 , which was confined to registered Holsteins. Therefore, the number of recorded cows is approximately $4.9 \%$ of the number of specialized dairy cows in the country.

The development of the Holstein breed in Mexico in the last 30 yr has been based mainly on imports of live animals, semen, and embryos from the United States, Canada, and, more recently, from Europe and Oceania (Powell, 1983; Valencia et al., 1999).

Selection responses in Mexico from the use of USselected Holstein sires, evaluated from the regression of deviations of daughters on sire PTA, have been estimated as 0.78 (Stanton et al., 1991), whereas the observed responses inside the United States have been close to 1 (Powell and Norman, 1984). These differences have been attributed both to smaller genetic variances in Latin America, which are associated with lower production levels, and to genetic correlations smaller than 
1 between countries (Stanton et al., 1991; CienfuegosRivas et al., 1999). Cienfuegos-Rivas et al. (1999) estimated values between 0.60 and 0.93 for the genetic correlations between Mexico and the United States.

No previous studies have evaluated nonlinear relationships between selection responses in Mexico and genetic evaluation of sires from Canada and the United States. The use of these models might assess whether genes with a large positive or negative effect in a first country with a better environment would have a greater environmental sensitivity that might decrease or increase their response in a second country with a more restrictive environment.

Some authors have found nonlinear relationships between production and conformation characters in dairy cattle (Fuerst-Waltl et al., 1998). The theoretical support for such a relationship is an increasing competition for the use of the same resources once a threshold is reached (Sölkner and James, 1994). These types of effects may theoretically lead to a concave or sigmoidal relationship between evaluations and selection responses, characterized by a shift at the extremes of the distributions. Therefore, these types of interactions may lead to nonlinear relationships between genetic evaluation at a high environmental level and its genetic response at a low environmental level.

The objective of this study was to evaluate the presence of genotype $\times$ environment interactions (GEI) for milk production in Holstein cattle by using linear and polynomial regression models of a second- and thirdorder degree to predict the contemporary deviations of daughters in Mexico from PTA of Canadian and US sires. The genetic correlations of production traits between countries were also evaluated.

\section{MATERIALS AND METHODS}

\section{Data}

Genetic evaluations for Mexico were obtained by the Holstein Association of Mexico for 2,502 bulls born from 1985 to 1998 . The evaluations were calculated by using a single-trait repeatability animal model. Official genetic evaluations for the year 2001 in Canada were obtained from the Web site of the Canadian Dairy Network (2001) for 5,680 bulls born from 1958 to 1997. Official genetic evaluations for the year 2001 in the United States were obtained from the Web site of the Animal Improvement Programs Laboratory of the USDA (USDA-ARS, 2001) for 52,127 bulls born between 1950 and 2001. The data for bulls with evaluations in Mexico-United States and Canada-Mexico were edited in a file with a minimum reliability of 0.75 . This was done to reduce the influence of random environ- mental and genetic effects on the averages of the daughters of each bull (Montaldo, 2001). The reliability was defined as the estimated $\mathrm{r}_{\mathrm{T}, \mathrm{PTA}}^{2}$, where $\mathrm{T}$ is the true transmitting ability of the sire.

When initially combining the files, 967 bulls had an evaluation in Mexico and the United States, whereas 382 had an evaluation in Mexico and Canada. When the data were edited to include only bulls with at least the minimum reliability, only 73 bulls had evaluations in Mexico and the United States, and only 40 had evaluations in Mexico and Canada. Among them, 40 bulls having evaluations in Canada and the United States were used as the control group. All the genetic evaluations were expressed as PTA in 305-d matureequivalent milk production $(\mathrm{kg})$. The information from 1 sire having a Studentized residual of 3.6 standard deviations in the linear regression analyses (see below) was excluded from the final data set because it had the potential to bias the estimates.

Two environmental levels were defined according to the 305-d mature-equivalent milk production average of the herd mates of the daughters of each sire in Mexico for each group of sires. Values below the general mean $(10,488 \mathrm{~kg})$ for the sires with information both in Mexico and the United States were classified as a low environmental level $(\mathrm{n}=37)$, and the values above the general mean $(\mathrm{n}=36)$ were considered as a high environmental level. Values below the general mean $(10,585 \mathrm{~kg})$ for the sires with information both in Mexico and Canada were classified as a low environmental level $(n=20)$, and the values above the general mean $(n=20)$ were considered as a high environmental level (Table 1).

\section{Analysis and Statistical Models}

Polynomial regression models of a first-, second-, and third-order degree were fitted, with the contemporary deviations of the daughters in Mexico as the dependent variable and the PTA of Canada or the United States as the independent variable. The contemporary deviations of the daughters in Mexico were calculated by deregressing the Mexican PTA by dividing it by the reliability of the evaluation (Goddard, 1985).

The regression coefficients and the adjusted coefficients of determination $\left(\mathrm{R}_{\text {adj }}^{2}\right)$ were obtained for all models with the REG procedure of the SAS program, version 8.0 (SAS Institute, Inc., Cary, NC), using ordinary least squares (Littell et al., 1991). The analyses were performed for the complete set and by environmental level. Hypothesis testing regarding the regression coefficients being lower than 1.0 and for differences between them was done by using independent $t$-tests (Gill, 1978). 
Table 1. Regression coefficients for linear models between countries

\begin{tabular}{|c|c|c|c|c|c|c|}
\hline \multirow[b]{2}{*}{ Country pair } & \multirow{2}{*}{$\begin{array}{l}\text { Environmental } \\
\text { level }\end{array}$} & \multirow{2}{*}{$\begin{array}{c}\text { Milk production } \\
\text { average of } \\
\text { contemporaries }(\mathrm{kg})\end{array}$} & \multirow[b]{2}{*}{ Sires (no.) } & \multicolumn{2}{|c|}{ Regression coefficient } & \multirow{2}{*}{$\begin{array}{c}\text { Adjusted } \\
\text { coefficient of } \\
\text { determination }(\%)\end{array}$} \\
\hline & & & & Intercept $\left(\mathrm{b}_{0}\right)$ & Slope $\left(b_{1}\right)$ & \\
\hline \multirow[t]{3}{*}{ Mexico-United States } & All & 10,487 & 73 & $463.5 \pm 46.0$ & $1.01 \pm 0.13^{\mathrm{NS}}$ & 43.4 \\
\hline & High & 11,267 & 36 & $294.0 \pm 93.1$ & $1.41 \pm 0.24^{\mathrm{NS}}$ & 49.3 \\
\hline & Low & 9,727 & 37 & $508.5 \pm 54.9$ & $0.89 \pm 0.19^{\mathrm{NS}}$ & 37.0 \\
\hline \multirow[t]{3}{*}{ Canada-Mexico } & All & 10,585 & 40 & $156.0 \pm 109.8$ & $0.93 \pm 0.16^{\mathrm{NS}}$ & 45.7 \\
\hline & High & 11,294 & 20 & $-116.3 \pm 224.5$ & $1.32 \pm 0.31^{\mathrm{NS}}$ & 47.2 \\
\hline & Low & 9,876 & 20 & $235.6 \pm 126.6$ & $0.78 \pm 0.19^{\mathrm{NS}}$ & 44.6 \\
\hline
\end{tabular}

The genetic correlations between countries $\left(r_{q}\right)$ were estimated from the observed correlations among the PTA of each bull in 2 countries and their average reliabilities, according to the following formula (Calo et al., 1973):

$$
r_{g}=\frac{r_{o}}{\sqrt{\text { arel }_{i} \times \text { arel }_{j}}},
$$

where $r_{g}$ is the genetic correlation, $r_{o}$ is the observed correlation among evaluations, arel $_{i}$ is the average reliability of Mexican PTA, and arel $_{j}$ is the average reliability of Canadian or US PTA.

The denominator of equation [1] is the expected correlation between evaluations if $r_{g}=1$. Genetic correlations were obtained for all data and for sire groups formed within environmental level. Independent tests for the differences between correlation coefficients were done using the method of Fisher (Gill, 1978).

The observed correlation between countries as a measure of GEI may be sensitive to the presence of errors in the sire identification. Because sire misidentification rates of $10 \%$ or higher are common in dairy populations (Visscher et al., 2002), a simulation study was carried out to test this hypothesis. To evaluate the impact of errors of paternity in the genetic correlation estimates, with the basic assumptions used in this study, we simulated 100 replicates of populations of 1,000 sires with an average of 100 daughters in each environment by using a sire model with normally distributed effects of sire and environment (Van Vleck, 1993). A Poisson distribution was assumed for the number of daughters per sire. In one set, the PTA of each sire was obtained without sire identification errors; in a second one, $20 \%$ of the true sires' breeding values were replaced by breeding values of nonrelated sires. The heritability was 0.25 . The PTA obtained for the 2 samples were correlated and compared.

\section{RESULTS}

\section{Regression Models with All Data}

The $\mathrm{R}_{\text {adj }}^{2}$ for the linear regression models were 43.4 and $45.7 \%$ for Mexico-United States and CanadaUnited States, respectively (Table 1). The $\mathrm{R}_{\text {adj }}^{2}$ for second- and third-degree polynomial models showed similar or smaller values than the values observed for the linear models, whereas quadratic and cubic effects were not significant $(P>0.05$; results not shown). The slope $\left(\mathbf{b}_{1}\right)$ for the linear model for Mexico-United States was 1.01, and for Canada-Mexico it was 0.93 (Table 1). None was significantly different from unity. The intercept $\left(\mathbf{b}_{\mathbf{0}}\right)$ of the linear model was larger for MexicoUnited States (463.5 kg) than for Canada-Mexico (156.0 $\mathrm{kg}$; Table 1).

\section{Regression Models by Environmental Level}

Table 1 shows that the $\mathrm{R}_{\text {adj }}^{2}$ for the high environmental level for the Mexico-US linear model was larger than

Table 2. Actual, expected, and genetic correlation coefficients for sire evaluations in different countries

\begin{tabular}{|c|c|c|c|c|c|c|c|}
\hline \multirow[b]{2}{*}{ Country pair } & \multirow{2}{*}{$\begin{array}{l}\text { Environmental } \\
\text { level }\end{array}$} & \multirow[b]{2}{*}{ Sires (no.) } & \multicolumn{2}{|c|}{ Average reliability } & \multicolumn{3}{|c|}{ Correlation } \\
\hline & & & Exporting & Importing & Actual & Expected & Genetic \\
\hline \multirow[t]{3}{*}{ United States-Mexico } & All & 73 & 0.98 & 0.81 & 0.66 & 0.89 & $0.74^{* *}$ \\
\hline & High & 36 & 0.98 & 0.80 & 0.70 & 0.89 & $0.79^{* *}$ \\
\hline & Low & 37 & 0.97 & 0.81 & 0.62 & 0.89 & $0.70 * *$ \\
\hline \multirow[t]{3}{*}{ Canada-Mexico } & All & 40 & 0.95 & 0.80 & 0.68 & 0.88 & $0.77^{* *}$ \\
\hline & High & 20 & 0.96 & 0.80 & 0.71 & 0.88 & 0.81 \\
\hline & Low & 20 & 0.94 & 0.81 & 0.68 & 0.88 & $0.78^{*}$ \\
\hline Canada-United States & All & 40 & 0.99 & 0.95 & 0.89 & 0.97 & 0.92 \\
\hline
\end{tabular}

${ }^{*} P<0.05 ;{ }^{*} P<0.01$. 
that observed for the low environmental level (49.3 vs. $37.0 \%$ ), whereas a similar trend was observed for Canada-Mexico (45.7 vs. $44.6 \%$ ). Quadratic and cubic effects within environmental level were nonsignificant $(P$ $>0.05)$ for all country-production level combinations (results not shown).

The largest value for $b_{1}$ was found for Mexico-United States in the high environment $(1.41 \mathrm{~kg})$, and this differed from the result observed in the low environment $(0.89 \mathrm{~kg} ; P<0.01)$. For Canada-Mexico environments, significant differences were also observed $(P<0.01)$, with $b_{1}$ equal to $1.32 \mathrm{~kg}$ in the high environment and $b_{1}$ equal to $0.78 \mathrm{~kg}$ in the low environment.

The values of $b_{0}$ were greater for Mexico-United States for the low level of environment $(508.5 \mathrm{~kg} ; P<0.01)$ than for the high environment $(294.0 \mathrm{~kg} ; P<0.05)$. A similar trend was found for Canada-Mexico, with values of $235.6 \mathrm{~kg}(P<0.05)$ for the low environment and $-116.3 \mathrm{~kg}(P>0.05)$ for the high environment.

\section{Genetic Correlations Between Countries}

Table 2 shows the genetic correlations between Mexico and the United States (0.74), between Canada and Mexico (0.77), and between Canada and the United States (0.92); this last correlation was approximately similar to that observed by other authors between Canada and the United States for milk yield (0.95 to 1.00; Powell and Sieber, 1992). Both the genetic correlations of Mexico-United States and Canada-Mexico were smaller $(P<0.01)$ than the genetic correlation of Canada-United States (0.92), which is indicative of GEI.

The genetic correlation for the high environmental level between Mexico and the United States was 0.79 and 0.81 for Canada-Mexico. Only the value for Mexico-United States was lower than the value for Canada-United States $(P<0.05$; Table 2$)$. For the low environmental level, the genetic correlation between Mexico and the United States was 0.70, and between Mexico and Canada it was 0.78 . These 2 values were smaller than the genetic correlation between Canada and the United States (0.92; Table 2).

\section{DISCUSSION}

\section{Selection Responses}

The lack of departure from linearity in the analyzed data indicated no evidence of a differential expression of genes for a particularly high or low milk yield between Canada and Mexico and between the United States and Mexico. The slopes for the linear model using all data were 1.01 for Mexico-United States and were 0.93 for
Canada-Mexico (Table 1). Most previous estimates for Mexico and the United States [e.g., by Powell and Dickinson (1977; 1.01), Powell and Wiggans (1991; 0.79), and Stanton et al. (1991; 0.78] were also not far from unity. Ojango and Pollott (2002) found a much smaller response value (0.44) for Holstein sires used in Kenya and evaluated in the United Kingdom. The relatively larger slopes observed in this analysis compared with most previous findings could be related to increased production levels and variability for milk yield in the Mexican Holstein population across time (Valencia et al., 2004).

Departures from unity in responses may indicate not only GEI effects, but also scale effects on the variances associated with differences between production levels, mainly caused by environmental and genetic level differences between the samples. Slopes may also be affected by the reliabilities of the PTA (Calo et al., 1973; Wilmink et al., 1986). The observed differences in responses between sires from the low and high levels (Table 1) were therefore expected. Verdugo et al. (2004) estimated that the genetic responses for milk yield for US sires increased from 0.38 to 0.55 in Argentina, from 0.49 to 1.54 in Chile, and from 0.52 to 1.2 in the United States according to the production level of the herd.

Differences in intercepts between countries are difficult to interpret because there are differences between the US and Canadian definitions of the genetic bases for each country. For the United States, a 1995 genetic base was used, compared with a 2001 genetic base for Canada. Differences between high and low environmental levels may also be the result of differences in the slopes.

\section{Genetic Correlations}

There is conflicting previous evidence regarding the presence of GEI for milk production between Canada and Mexico and between Mexico and the United States. Powell and Dickinson (1977), Powell and Wiggans (1991), and Powell and Sieber (1992) found values close to unity for the genetic correlations for milk yield between Mexico and the United States obtained from correlations between PTA of the same sires used in both countries. Powell and Sieber (1992) found the same value (genetic correlation $=1$ ), between Mexico and Canada when using the same methodology. Stanton et al. (1991) found a genetic correlation of 0.90 for milk production between Mexico and the United States, whereas McDowell et al. (1976) found a value of 0.86 . However, other authors (Cienfuegos-Rivas et al., 1999) found a value of $<1.0(0.63)$ for the genetic correlation for milk yield between Mexico and the United States. Valencia et al. (2008), in Mexico, found evidence of a 
Table 3. Simulated correlations between sire evaluations from 2 daughter samples with and without paternity errors

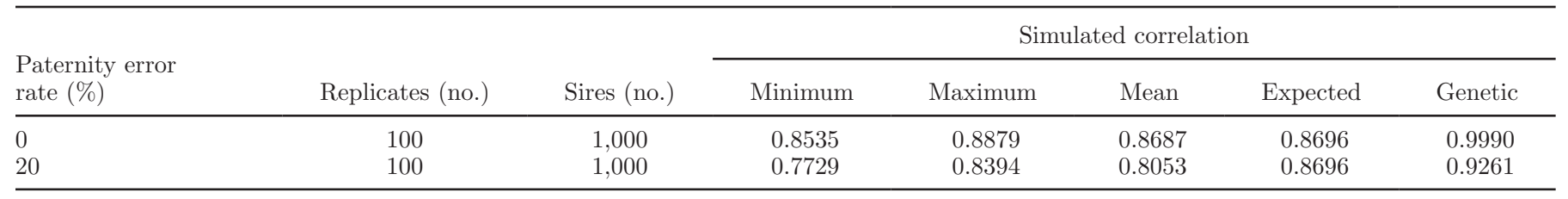

genetic correlation for milk yield between regions with extreme values for this trait that was significantly lower than 1.0 (0.38).

In other Holstein populations, Ojango and Pollott (2002) found a genetic correlation for milk yield of 0.49 between Kenya and the United Kingdom. On the other hand, Castillo-Juárez et al. (2000) observed a genetic correlation for milk yield between low and high environmental levels of 0.98 in a northeastern US Holstein population.

The trend toward a smaller genetic correlation for milk yield at the low versus high environmental level observed in several other studies (Stanton et al., 1991; Cienfuegos-Rivas et al., 1999; Costa et al., 2000) was also observed between Mexico and the United States and, to a lesser extent, between Canada and Mexico in our study (Table 2), although neither of these differences was significant $(P>0.05)$. Here, we divided the environment based on differences in the average production of the herd mates for each sire, thereby perhaps limiting the differences in environmental levels between the high and low groups when compared with studies that classified herds based on environmental levels before estimating the sire PTA. On the other hand, our approach may better reflect the effect of environmental level on sire ranking because sires were evaluated in a realistic range of environments.

From the simulation study without paternity errors, the average simple correlation among the PTA of the 2 samples was 0.8687 , compared with the expected value of 0.8696 (the square root of the products of the reliabilities), giving a genetic correlation value of 0.9990 (Table 3 ). With a paternity error rate of $20 \%$, the average value of the simple correlation between samples decreased to 0.8053 . In this example, we estimated the genetic correlation as 0.9261 (Table 3). These results indicate that when calculating the genetic correlations from simple correlations between evaluations of sires from 2 groups of daughters, the paternity errors may wrongly suggest the presence of GEI. These results also indicate that with a relatively large number of daughters, the effect of paternity errors is likely to explain less than $10 \%$ of the reduction in genetic correlations.

Upward biases are also possible as the result of preferential treatment of sires with high PTA. Downward biases are also possible as the result of differences be- tween methods for predicting breeding values within country or of differences in trait definitions and because the samples of sires used were selected, although these effects are likely to be small between Canada and the United States (Powell and Sieber, 1992).

Considering the trends obtained in this study across environmental levels, the responses and genetic correlations might be reduced further if a more extensive sample of Mexican cows with lower variability and environmental level for milk yield were used - that is, a sample of sires progeny tested with a random sample of specialized dairy cows instead of herds of pedigreed Holsteins enrolled in milk recording programs, which are a part of an small, elite population with better environmental conditions than the average dairy cow population in Mexico. In this study, the average mature-equivalent milk production level per cow was approximately $10,500 \mathrm{~kg}$ and was approximately 9,800 $\mathrm{kg}$ for the low environmental level (Table 1), compared with an approximate estimate of $7,271 \mathrm{~kg}$ of matureequivalent milk production per cow for the specialized dairy population of Mexico (Servicio de Información Agroalimentaria y Pesquera, Secretaría de Agricultura, Ganadería, Desarrollo Rural, Pesca y Alimentación, 2009).

\section{CONCLUSIONS}

Selection responses for milk yield found for Mexico in this study were close to 1.0. Genetic correlations indicated a moderate degree of GEI interaction with both Canada and the United States, although the genetic correlations were relatively high $(\geq 0.74)$. These values were smaller than the genetic correlation between Canada and the United States, suggesting the presence of GEI between Mexico and the United States and between Canada and Mexico. In any case, sire misidentification may bias downward the genetic correlation estimates between countries.

Selection responses were larger in high-production environments than those observed for low-production environments. There was also a trend for greater genetic correlations at a high environmental level.

Because the relationships between the deviations of daughters in Mexico and genetic evaluations in the United States and Canada were essentially linear, the 
bulls to be used in Mexico could be selected on the basis of their PTA in the United States and Canada, although with slightly smaller selection responses, given the GEI observed for this trait in the herds at lower environmental levels. Hence, multicountry evaluations that include Mexican records might be a better way to identify the best sires to be used in Mexico for milk production improvement.

\section{ACKNOWLEDGMENTS}

The authors thank Marcia Castillo-Mendoza from the Universidad CESSA in Mexico City for proofreading the manuscript.

\section{REFERENCES}

Calo, L. L., R. E. McDowell, L. D. Van Vleck, and P. D. Miller. 1973. Genetic aspects of beef production among Holstein-Friesians pedigree selected for milk production. J. Anim. Sci. 37:676-682.

Castillo-Juárez, H., P. A. Oltenacu, R. W. Blake, C. E. McCulloch, and E. G. Cienfuegos-Rivas. 2000. Effect of herd environment on the genetic and phenotypic relationships among milk yield, conception rate, and somatic cell score in Holstein cattle. J. Dairy Sci. 83:807-814.

Canadian Dairy Network. 2001. Official genetic evaluations. http:// www.cdn.ca/ Accessed Mar. 10, 2001.

Cienfuegos-Rivas, E. G., P. A. Oltenacu, R. W. Blake, S. J. Schwager, H. Castillo-Juarez, and F. J. Ruiz. 1999. Interaction between milk yield of Holstein cows in Mexico and the United States. J. Dairy Sci. 82:2218-2223.

Costa, C. N., R. W. Blake, E. J. Pollak, P. A. Oltenacu, R. L. Quaas, and S. R. Searle. 2000. Genetic analysis of Holstein cattle populations in Brazil and the United States. J. Dairy Sci. 83:2963-2974.

Fuerst-Waltl, B., J. Sölkner, A. Essl, I. Hoeschele, and C. Fuerst. 1998. Non-linearity in the genetic relationship between milk yield and type traits in Holstein cattle. Livest. Prod. Sci. 57:41-47.

Gill, J. L. 1978. Design and Analysis of Experiments in the Animal and Medical Sciences. 1st ed. Vol. 1.1. The Iowa State University Press, Ames.

Goddard, M. 1985. A method of comparing sires evaluated in different countries. Livest. Prod. Sci. 13:321-331.

Littell, R. C., R. J. Freund, and P. C. Spector. 1991. SAS System for Linear Models. SAS Series in Statistical Applications. Version 8.0. 3rd ed. SAS Inst. Inc., Cary, NC.

McDowell, R. E., G. R. Wiggans, J. K. Camoens, L. D. Van Vleck, and D. G. St. Louis. 1976. Sire comparison for Holsteins in Mexico versus the United States and Canada. J. Dairy Sci. 59:298-304.
Montaldo, H. H. 2001. Genotype-environment interactions in livestock breeding programs: A review. Interciencia 26:229-235.

Ojango, J. M., and G. E. Pollott. 2002. The relationship between Holstein bull breeding values for milk yield derived in both the UK and Kenya. Livest. Prod. Sci. 74:1-12.

Powell, R. L. 1983. Evaluation of Holstein sires used in Mexico. Holstein World 10:186-187.

Powell, R. L., and F. N. Dickinson. 1977. Progeny test of sires in the United States and in Mexico. J. Dairy Sci. 60:1768-1772.

Powell, R. L., and H. D. Norman. 1984. Response within herd to sire selection. J. Dairy Sci. 67:2021-2027.

Powell, R. L., and M. Sieber. 1992. Direct and indirect conversion of bull evaluations for yield traits between countries. J. Dairy Sci. 75:1138-1146.

Powell, R. L., and G. R. Wiggans. 1991. Animal model evaluations for Mexican Holsteins. J. Dairy Sci. 74:1420-1427.

Servicio de Información Agroalimentaria y Pesquera, Secretaría de Agricultura, Ganadería, Desarrollo Rural, Pesca y Alimentación. 2009. Home page. http://www.siap.sagarpa.gob.mx/ Accessed Apr. 3, 2009.

Sölkner, J., and J. James. 1994. Curvilinearity in the relationship between traits competing for resources: A genetic model. Proc. 5th World Congr. Genet. Appl. Livest. Prod. (Guelph, Ontario, Canada) 19:151-154.

Stanton, T. L., R. W. Blake, R. L. Quaas, L. D. Van Vleck, and M. J. Carabaño. 1991. Genotype $\times$ environment interactions for Holstein milk yield in Colombia, México, and Puerto Rico. J. Dairy Sci. 74:1700-1714.

USDA-ARS. 2001. Official Genetic Evaluations. http://www.aipl. ursusda.gov/ Accessed Mar. 15, 2001.

Valencia, P. M., F. J. Ruiz, and H. H. Montaldo. 2004. Genetic and environmental variance components for milk yield across regions, time periods and herd levels for Holstein cattle in México. Rev. Cient.-Fac. Cien. 14:404-411.

Valencia, P. M., F. J. Ruiz, H. H. Montaldo, J. F. Keown, and L. D. Van Vleck. 1999. Evaluación genética para la producción de leche en ganado Holstein en México. Tec. Pecu. Mex. 37:1-8.

Valencia, P. M., H. H. Montaldo, and F. J. Ruiz. 2008. Genotype by region interactions for milk production in dairy cattle. Arch. Zootec. 57:457-463.

Van Vleck, L. D. 1993. Selection Index and Introduction to Mixed Model Methods. CRC Press, Boca Raton, FL.

Verdugo, R., A. Jara, R. W. Everett, and N. Barría. 2004. Selection response of U.S. Holstein sires for milk production in Chile and Argentina. Livest. Prod. Sci. 88:9-16.

Visscher, P. M., J. A. Woolliams, D. Smith, and J. L. Williams. 2002. Estimation of pedigree errors in the UK dairy population using microsatellite markers and the impact on selection. J. Dairy Sci. $85: 2368-2375$.

Wilmink, J. B., A. Meijering, and B. Engel. 1986. Conversion of breeding values for milk from foreign populations. Livest. Prod. Sci. 14:223-229. 